\title{
Some energy balances of dairy cows at high day and moderate night temperatures
}

\author{
A. J. H. van Es ${ }^{1}$, M. W. A. Verstegen ${ }^{2}$, M. S. Saleh Youssef ${ }^{3}$ and H. J. Nijkamp ${ }^{1}$ \\ Laboratory of Animal Physiology, Agricultural University, Wageningen, The Nether- \\ lands
}

Received 19 April, 1968

\section{Summary}

Three energy balance experiments of one month each were performed with 2 Friesian cows producing initially 14 and $10 \mathrm{~kg}$ milk. In the latter half of trials 1 and 2 both cows were kept one week at $15^{\circ} \mathrm{C}$ and one week from 8 a m till $5 \mathrm{p} \mathrm{m}$ at $30^{\circ} \mathrm{C}$ and from $5 \mathrm{p} \mathrm{m}$ till $8 \mathrm{a} \mathrm{m}$ at $25^{\circ} \mathrm{C}$. The rations consisted of concentrates with either much or little hay. In the third trial the animals were kept during the first and last two days of the second half of the trial at $20^{\circ} \mathrm{C}$ and during the other days at $30^{\circ} \mathrm{C}$ during the day and at $25^{\circ} \mathrm{C}$ during the night and one or two days at $30^{\circ} \mathrm{C}$ continuously. The ration consisted of concentrates and some straw. Feed intake especially of roughage, was markedly negatively influenced at $30^{\circ} \mathrm{C}$ applied continuously and at $30^{\circ} / 25^{\circ}$ with the ration with much hay, but hardly at $30^{\circ} / 25^{\circ}$ with the other rations. At $30^{\circ} / 25^{\circ}$ there was no influence on methane or urine energy loss, probably a small positive effect on digestibility, and no or only a small negative effect on the efficiency of the utilisation of metabolisable energy for maintenance and production.

\section{Introduction}

Dairy cows can stand low environmental temperatures much better than high temperatures (Payne, 1966; Johnson et al., 1966 and Moody et al., 1967). It was our experience with veal calves, that these animals have fewer inconveniences of a warm environment if periods of high temperatures are alternated with periods of moderate temperatures (van Es and Nijkamp, 1967). This might also apply to dairy cows. If the periods with high temperatures were applied during the day and those with moderate temperatures during the night the resulting environmental climate would be not far from the indoor climate often found in subtropical countries. As rations with high percentages of roughage are said to impose a higher heat load on the animals than rations with less roughage, the use of rations low in roughage might be another means of decreasing the disadvantageous effects of high environmental temperatures on dairy cows.

1 Laboratory of Animal Physiology, Wageningen, The Netherlands.

2 Laboratory of Animal Husbandry, Wageningen, The Netherlands.

s Department of Animal Production, Ministry of Agriculture, Cairo, Egypt. 
In this pilot experiment in reversal trials two lactating Friesian cows were fed rations high and low in roughage during both periods with normal temperatures and periods with day temperatures of $30^{\circ} \mathrm{C}$ and night temperatures of $25^{\circ} \mathrm{C}$.

\section{Experimental}

Two lactating Friesian cows 9 and 10, age 11 and 4.5 years respectively, which initially were in their 2 nd and 3 rd month of pregnancy were used in three experiments. Each experiment lasted 28 days. Balances were measured during each of the last two weeks of the trial called first and second experimental week while the animals continuously were in a respiration chamber. In the first experiment animal 9 received a ration of $4 \mathrm{~kg}$ hay, $6 \mathrm{~kg}$ of a concentrate mixture ('A-brok') and $3 \mathrm{~kg}$ dried sugarbeet pulp (ration $\mathrm{C}$ ) and animal 10 a ration of $8 \mathrm{~kg}$ hay, $5 \mathrm{~kg}$ 'A-brok' and $2 \mathrm{~kg}$ sugarbeet pulp (ration $\mathbf{R}$ ). In the second experiment ration $\mathbf{R}$ was fed to animal 9 and ration $C$ to animal 10 . In the third experiment both animals obtained the same ration (S) which consisted of $4 \mathrm{~kg}$ straw and $9 \mathrm{~kg}$ of a mixture of barley meal, cottonseed meal and dried sugarbeet pulp. To increase the heat load on the animals which only produced $11 \mathrm{~kg}$ of milk in the beginning and $6 \mathrm{~kg}$ at the end of the series, the rations were given in such quantities that in the three experiments some 2000,3500 and $6000 \mathrm{kcal}$ energy respectively in body protein and fat were stored. In both the first and second experiments one cow was kept during the first of the two experimental weeks at $15-16^{\circ} \mathrm{C}$ with a relative humidity of 60

Table 1 Ration, temperature and heat expenditure

\begin{tabular}{|c|c|c|c|c|c|c|c|c|c|c|}
\hline \multirow[b]{2}{*}{$\begin{array}{c}\text { Exp. } \\
n r\end{array}$} & \multirow[b]{2}{*}{$\begin{array}{l}\text { Exp. } \\
\text { week }\end{array}$} & \multirow[b]{2}{*}{$\begin{array}{c}\text { Exp. } \\
\operatorname{day}(s)\end{array}$} & \multicolumn{4}{|c|}{ Animal 9} & \multicolumn{4}{|c|}{ Animal 10} \\
\hline & & & ration ${ }^{x}$ & $\begin{array}{l}\text { tempe } \\
\text { day }\end{array}$ & $\begin{array}{c}\text { erature } \\
\text { night }\end{array}$ & $\begin{array}{l}\text { heat exp. }{ }^{2} \\
\quad(\text { kcal })\end{array}$ & ration 1 & $\begin{array}{l}\text { tempe } \\
\text { day }\end{array}$ & $\begin{array}{r}\text { erature } \\
\text { night }\end{array}$ & $\begin{array}{l}\text { heat exp. }{ }^{2} \\
(\text { kcal })\end{array}$ \\
\hline 1 & 1 & 2 & $\mathrm{C}$ & 29.6 & 24.7 & 18196 & $\mathbf{R}$ & 15.6 & 15.6 & 20814 \\
\hline 1 & 1 & $6+7$ & C & 29.6 & 24.7 & 18418 & $\mathbf{R}$ & 15.6 & 15.6 & 20180 \\
\hline 1 & 2 & 9 & $\mathrm{C}$ & 16.1 & 16.1 & 18521 & $\mathbf{R}$ & 29.5 & 25.0 & 20538 \\
\hline 1 & 2 & $13+14$ & $\mathrm{C}$ & 16.1 & 16.1 & 17994 & $\mathbf{R}$ & 29.5 & 25.0 & 19987 \\
\hline 2 & 1 & 2 & $\mathbf{R}$ & 15.9 & 15.9 & 19943 & $\mathrm{C}$ & 29.5 & 24.5 & 18934 \\
\hline 2 & 1 & $3+4$ & $\mathbf{R}$ & 15.9 & 15.9 & 20008 & C & 29.5 & 24.5 & 19518 \\
\hline 2 & 1 & $6+7$ & $\mathbf{R}$ & 15.9 & 15.9 & 19935 & $\mathrm{C}$ & 29.5 & 24.5 & 18923 \\
\hline 2 & 2 & $9+10$ & $\mathbf{R}$ & 29.3 & 24.5 & 20909 & $\mathbf{C}$ & 15.8 & 15.8 & 18686 \\
\hline 2 & 2 & $11+12$ & $\mathbf{R}$ & 29.3 & 24.5 & 19824 & $\mathrm{C}$ & 15.8 & 15.8 & 18702 \\
\hline 2 & 2 & $13+14$ & $\mathbf{R}$ & 29.3 & 24.5 & 19495 & C & 15.8 & 15.8 & 18787 \\
\hline 3 & 1 & $1+2$ & $\mathbf{S}$ & 20.2 & 20.2 & 17929 & $\mathbf{S}$ & 20.9 & 20.9 & 18168 \\
\hline 3 & 1 & $3+4,5$ & $\mathbf{S}$ & 30.2 & 25.2 & & $\mathrm{~S}$ & 30.0 & 25.8 & \\
\hline 3 & 1 & $6+7$ & $\mathbf{S}$ & 30.2 & 25.2 & 18898 & $\mathbf{S}$ & 30.0 & 25.8 & 18936 \\
\hline 3 & 2 & 9 & $\mathrm{~S}$ & 30.2 & 30.2 & & $\mathbf{S}$ & 30.5 & 30.5 & \\
\hline 3 & 2 & 10 & $\mathbf{S}$ & 25.1 & 25.1 & & $\mathbf{S}$ & 30.3 & 30.3 & \\
\hline 3 & 2 & $9+10$ & $S$ & & & 18874 & $\mathbf{S}$ & & & 18527 \\
\hline 3 & 2 & $11+12$ & $\mathbf{S}$ & 30.0 & 24.8 & 18890 & $\mathbf{S}$ & 29.8 & 25.4 & 17972 \\
\hline 3 & 2 & $13+14$ & $\mathbf{S}$ & 20.2 & 20.2 & 18566 & $\mathbf{S}$ & 20.8 & 20.8 & 18302 \\
\hline
\end{tabular}

1 $\mathrm{C}=$ mixed ration with little hay; $\mathrm{R}=$ mixed ration with much hay; $\mathrm{S}=$ mixed ration with little straw.

$\approx$ Computed from respiratory gasexchange. 
$70 \%$ while the other animal was kept at $29-30^{\circ} \mathrm{C}$ from 8 a $\mathrm{m}$ till $5 \mathrm{p} \mathrm{m}$ (R.H. app. $65 \%)$ and at $24-25^{\circ} \mathrm{C}$ from $5 \mathrm{p} \mathrm{m}$ till 8 a $\mathrm{m}$ (R.H. app. $65 \%$ ). In the second experimental weeks these conditions were reversed. During the two experimental weeks of the third experiment both moderate $\left(20^{\circ}\right.$; days $\left.1,2,13,14\right)$, high and moderate (day $30^{\circ}$, night $25^{\circ}$; days $3-7$ and 10-12) and high $\left(30^{\circ}\right.$, day 9 for cow 9 and days 9 and 10 for cow $10 ; 25^{\circ}$, day 10 for cow 9) temperatures were used, while relative humidities again were app. $65 \%$.

A survey of the rations and temperatures is given in Table 1. Analytical and technical methods were the same as described earlier (van Es, 1961, 1966).

\section{Results (See Tables 2 and 3)}

Feed residues were negligible with the low roughage ration $\mathrm{C}$. With the high roughage ration $R$ at $15^{\circ} \mathrm{C}$ daily 44 and $375 \mathrm{~g}$ hay were left by cows 9 and 10 respectively. During the high temperature week the daily residues of this ration $R$ increased continuously and averaged $1285 \mathrm{~g}$ and $700 \mathrm{~g}$ hay respectively. In the first experimental week of the third experiment the feed residues of ration $S$ were small (daily averages $23 \mathrm{~g}$ and $210 \mathrm{~g}$ straw). In the second week they were greater (496 $\mathrm{g}$ and $917 \mathrm{~g}$ straw) as soon after the continuous application of a temperature of $30^{\circ}$ considerable quantities of straw were left. Nearly complete feed intake was established again only at the end of the trial after one day at $20^{\circ}$. Moody et al. (1967) also noticed lower feed intake, when cows were exposed to high temperatures.

Methane production was not affected by temperature. Slightly less methane was produced on the ration with straw (S).

Energy digestibility was affected by temperature, with both the rations $\mathbf{R}$ and $\mathbf{C}$ it was 1-2 units higher at the high temperatures. This could not be explained by higher hay residues at the higher temperatures for ration $\mathrm{C}$ as these residues were negligible. For ration $\mathbf{R}$ it may, however, partly be explained by the higher hay residues. The 3 units higher digestibilities found in the second experimental week compared with the first week of experiment 3 may be explained by the higher straw residues of the second week.

Urine energy loss was neither affected by temperature nor by ration. This loss was for animal 9 in the second week of experiment 2 unusually high $(4.8 \%$ of the gross energy instead of between 2.5 and 3.6 as found in all other experimental weeks), probably due to an undetected error.

For the metabolisability of the energy of the rations the same can be said as for the energy digestibility, since methane and urine losses were not affected by temperature as said above. The value of animal 9 in the second week of the second trial has probably been found too low by 1.5 units due to the undetected urine error.

The milk energy produced daily during the experimental weeks with temperatures of $15^{\circ}$ or $20^{\circ}$ was approximately constant. During the weeks with higher temperatures for the rations $R$ and $S$ it decreased slightly while for ration $C$ there hardly was any decrease for cow 9 and a small increase for cow 10. 
Table 2 Digested and metabolisable energy and energy in methane and in urine as a perentage of energy intake

\begin{tabular}{|c|c|c|c|c|c|c|c|}
\hline $\operatorname{Exp}$ & Week & Ration & $\begin{array}{c}\text { Temp } \\
\left({ }^{\circ} \mathrm{C}\right)\end{array}$ & $\begin{array}{c}D E \\
(\%)\end{array}$ & $\begin{array}{l}M E \\
(\%)\end{array}$ & $\begin{array}{l}\mathrm{CH}_{4} \\
(\%)\end{array}$ & $\begin{array}{c}\text { Urine } \\
(\%)\end{array}$ \\
\hline \multicolumn{8}{|c|}{ Animal 9} \\
\hline 1 & $\begin{array}{l}1 \\
2\end{array}$ & $\begin{array}{l}\mathrm{C} \\
\mathrm{C}\end{array}$ & $\begin{array}{c}30 / 25 \\
15\end{array}$ & $\begin{array}{l}72.5 \\
70.2\end{array}$ & $\begin{array}{l}61.0 \\
59.1\end{array}$ & $\begin{array}{l}8.0 \\
7.8\end{array}$ & $\begin{array}{l}3.5 \\
3.4\end{array}$ \\
\hline 2 & $\begin{array}{l}1 \\
2\end{array}$ & $\begin{array}{l}\mathrm{R} \\
\mathrm{R}\end{array}$ & $\begin{array}{c}15 \\
30 / 25\end{array}$ & $\begin{array}{l}67.3 \\
68.2\end{array}$ & $\begin{array}{l}56.3 \\
55.5\end{array}$ & $\begin{array}{l}7.8 \\
7.9\end{array}$ & $\begin{array}{l}3.2 \\
4.8\end{array}$ \\
\hline 3 & $\begin{array}{l}1 \\
2\end{array}$ & $\begin{array}{l}S \\
S\end{array}$ & $\begin{array}{l}20>30 \\
30>20\end{array}$ & $\begin{array}{l}67.8 \\
70.1\end{array}$ & $\begin{array}{l}57.8 \\
59.1\end{array}$ & $\begin{array}{l}7.5 \\
7.6\end{array}$ & $\begin{array}{l}2.6 \\
3.6\end{array}$ \\
\hline \multicolumn{8}{|c|}{ Animal 10} \\
\hline 1 & $\begin{array}{l}1 \\
2\end{array}$ & $\begin{array}{l}\mathbf{R} \\
\mathbf{R}\end{array}$ & $\begin{array}{c}15 \\
30 / 25\end{array}$ & $\begin{array}{l}65.0 \\
67.2\end{array}$ & $\begin{array}{l}54.9 \\
57.0\end{array}$ & $\begin{array}{l}7.3 \\
7.4\end{array}$ & $\begin{array}{l}2.8 \\
2.8\end{array}$ \\
\hline 2 & $\begin{array}{l}1 \\
2\end{array}$ & $\begin{array}{l}\text { C } \\
\text { C }\end{array}$ & $\begin{array}{c}30 / 25 \\
15\end{array}$ & $\begin{array}{l}72.6 \\
71.9\end{array}$ & $\begin{array}{l}61.6 \\
61.2\end{array}$ & $\begin{array}{l}7.9 \\
8.1\end{array}$ & $\begin{array}{l}3.0 \\
2.6\end{array}$ \\
\hline 3 & $\begin{array}{l}1 \\
2\end{array}$ & $\begin{array}{l}S \\
S\end{array}$ & $\begin{array}{l}20>30 \\
30>20\end{array}$ & $\begin{array}{l}66.6 \\
69.5\end{array}$ & $\begin{array}{l}56.2 \\
59.9\end{array}$ & $\begin{array}{l}6.9 \\
7.1\end{array}$ & $\begin{array}{l}3.6 \\
2.5\end{array}$ \\
\hline
\end{tabular}

Table 3 Energy balances

\begin{tabular}{|c|c|c|c|c|c|c|}
\hline Exp. & Week & Ration & $\begin{array}{c}\text { Temp. } \\
\left({ }^{\circ} \mathrm{C}\right)\end{array}$ & $\begin{array}{c}M E \\
(k c a l)\end{array}$ & $\begin{array}{c}\text { Milk } \\
(\text { kcal })\end{array}$ & $\begin{array}{c}\text { Balance } \\
(\text { kcal })\end{array}$ \\
\hline
\end{tabular}

Animal 9

2

$\begin{array}{ll}1 & \mathrm{C} \\ 2 & \mathrm{C} \\ 1 & \mathrm{R} \\ 2 & \mathrm{~S} \\ 1 & \mathrm{~S} \\ 1 & \mathrm{~S} \\ 2 & \end{array}$

$\begin{array}{ccc}\text { C } & 30 / 25 & 29521 \\ \mathrm{C} & 15 & 28579 \\ \mathrm{R} & 15 & 31659 \\ \mathrm{R} & 30 / 25 & 28474 \\ \mathrm{~S} & 20 & 29994 \\ \mathrm{~S} & 30 / 25 & 29994 \\ \mathrm{~S} & 20 & 29563 \\ \mathrm{~S} & 30 / 25 & 29563\end{array}$

$\begin{array}{rrrccccr}1 & 1 & \mathbf{R} & 15 & 30206 & 8235 & 1552 & 9663 \\ 2 & 2 & \mathbf{R} & 30 / 25 & 31022 & 7889 & 3241 & 10517 \\ & 1 & \mathbf{C} & 30 / 25 & 29474 & 7939 & 2903 & 11158 \\ 3 & 2 & \mathbf{C} & 15 & 29410 & 7093 & 3844 & 11291 \\ & 1 & \mathbf{S} & 20 & 28740 & 5413 & 5593 & 11762 \\ & \mathbf{1} & \mathbf{S} & 30 / 25 & 28636 & 5413 & 4615 & 10846 \\ & 2 & \mathbf{S} & 20 & 28989 & 4362 & 6609 & 11578 \\ & 2 & \mathrm{~S} & 30 / 25 & 28970 & 4362 & 6707 & 11687\end{array}$

$\begin{array}{rrrccccr}1 & 1 & \mathbf{R} & 15 & 30206 & 8235 & 1552 & 9663 \\ 2 & 2 & \mathbf{R} & 30 / 25 & 31022 & 7889 & 3241 & 10517 \\ & 1 & \mathbf{C} & 30 / 25 & 29474 & 7939 & 2903 & 11158 \\ 3 & 2 & \mathbf{C} & 15 & 29410 & 7093 & 3844 & 11291 \\ & 1 & \mathbf{S} & 20 & 28740 & 5413 & 5593 & 11762 \\ & \mathbf{1} & \mathbf{S} & 30 / 25 & 28636 & 5413 & 4615 & 10846 \\ & 2 & \mathbf{S} & 20 & 28989 & 4362 & 6609 & 11578 \\ & 2 & \mathrm{~S} & 30 / 25 & 28970 & 4362 & 6707 & 11687\end{array}$

$\begin{array}{rrr}10228 & 1184 & 11699 \\ 9864 & 792 & 11509 \\ 8837 & 3593 & 11435 \\ 7822 & 648 & 9386 \\ 7457 & 5036 & 12497 \\ 7457 & 3941 & 11402 \\ 6213 & 5285 & 11760 \\ 6213 & 4725 & 11200\end{array}$

Animal 10

$1 \quad P_{30000}=$ energy in milk + energy balance, if $\mathrm{ME}$ had been $30000 \mathrm{kcal}$ assuming an efficiency of the utilisation of $\mathrm{ME}$ for milk and for balance of $60 \%$. This energy balance is the average of the balances obtained from ME and respiratory gasexchange and from $\mathrm{C}$ - and N-balances.

The respiration rate was counted several times a day. When the temperature was normal $\left(15^{\circ} \mathrm{C}\right)$ this rate averaged about 25 respirations per minute. With the high temperatures this rate rose to $65-80$. The animals evaporated more water, the evaporative heat as a percentage of heat expenditure rose from $30-35 \%$ at normal tem- 
perature to $45-55 \%$ at the high temperature environment. In the second period of trial three the respiration rate of cow 9 sometimes rose to 110 per minute for short periods. When the temperature was normal again it lasted about ten hours before the respiration rate was normal again. Higher rates of respiration associated with high environmental temperatures were found by Badreldin et al. (1951). Badr (1957) found higher rates of respiration at higher temperatures especially in cows and buffaloes fed straw instead of hay or grass.

The heat expenditure (Table 1) was hardly influenced by the temperature treatments; if influenced, then slightly higher heat expenditures were found at higher temperatures. The interpretation of the figures requires knowledge of intake of metabolisable energy and of energy depositions in milk and as body fat and protein. Therefore the total quantity of energy produced as milk and as body fat and protein (P30000) was computed at equal intake of metabolisable energy by adding energy balance to milk energy and by correcting the result to an intake of $30000 \mathrm{kcal} \mathrm{ME}$, assuming an efficiency of its utilisation for milk and gain of $60 \%$ (Table 3). In the third experiment the figures relating to $20^{\circ}$ and $30^{\circ} / 25^{\circ}$ respectively used were the weekly averages for milk energy and intake of ME and the 48- or 96-hour average for heat expenditure determined at either $20^{\circ}$ or $30^{\circ} / 25^{\circ}$. The body weights of the cows hardly varied during the three experiments. The figures P30000 of Table 3 vary little. For the ration $C$ (little hay) temperature did not effect the P30000-values. For ration $S$ (straw + concentrates) in the first experimental week of the third experiment these values were lower during the period with high temperatures. If indeed the digestibility at the high temperature is about 1.5 units higher than at normal temperature as was found with ration $C$ and probably also with ration $R$, then this may be explained in the following way. The figures of intake of ME apply to 2 cold and 5 warm days, thus assuming an 1.5 unit higher digestibility at the higher temperature, the intakes of ME during the cold and warm days were $430 \mathrm{kcal}$ less and $170 \mathrm{kcal}$ more respectively than those found as an average for the whole week. This would mean that the energy balances and the values P30000 during the cold days were computed $430 \mathrm{kcal}$ too high and during the warm days were computed 170 too low. This makes the differences between the warm and cold P-values much smaller, the P-values are only about 500 and $300 \mathrm{kcal}$ higher during the cold days.

The interpretation of the $P$-values obtained with ration $R$ and in the second experimental week with ration $S$ is rather difficult because of the increasing quantities of feed residues during the warm days. Two of the P-values found at the higher temperature are lower $(-2000$ and -600$)$ and the other two are higher $(+850$ and $+100 \mathrm{kcal})$ than at the lower temperature.

Summarising it seems correct to state that at equal intake of $M E$ the temperature of $30^{\circ}$ during the day and of $25^{\circ}$ during the night had probably no or only a small negative effect on the production of milk + body fat and protein.

\section{Discussion}

The results show that at higher temperature the animals were inclined to leave more roughage. This was very clear with ration $S$ when the temperature was $30^{\circ}$ for one or two days continuously. The effect was evident, though smaller, with the ration $\mathrm{R}$ with a temperaturecombination of $30^{\circ}$ during the day and $25^{\circ}$ during the 
night. There was hardly such an effect with the ration $\mathrm{C}$ during the periods with this temperaturecombination. Obviously this temperaturecombination was giving no - with ration $\mathrm{C}$ and $\mathrm{S}$ - or only small - with ration $\mathrm{R}$ - inconvenience to our cows. This is made clear also by the fact that it had no influence on methane and urine energy losses, probably a small, but positive effect on the digestibility and no or only a small negative effect on the utilisation of the metabolisable energy for maintenance and production. It remains a subject for further study to see whether the same applies to cows with higher milk yields.

\section{References}

Badr, M. F., 1957. The effect of roughage on body temperature and respiration rate of cows and buffaloes during summer in Egypt. Indian J. Dairy Sci., 10: 176.

Badreldin, A. L., Oloufa, H. M. and Ghany, M. A., 1951. Heat tolerance of cows and buffaloes in Egypt. Nature, $167: 856$.

Es, A. J. H. van, 1961. Between-animal variation in the amount of metabolisable energy required for the maintenance of cows. Versl, Landbouwk. Onderz. 67.5.

Es, A. J. H. van, 1966. Labour-saving methods for energy balance experiments with cattle; description of equipment and methods used. Neth. J. Agric. Sci., 14: 32-46.

Es, A. J. H. van and Nijkamp, H. J., 1967. Energy requirements of cattle. Proc. 4th Symp. Energy Metab. Warsaw.

Johnson, H. D., Kibler, H. H., Berry, I. L., Waynman, O. and Merilan, C. P., 1966. Environmental physiology and shelter engineering with special reference to domestic animals. LXX. Temperature and controlled feeding effects on lactation and related physiological reactions of cattle. Res. Bull. Missouri Agric. Exp. Stat. 902.

Moody, E. G., Soest, P. J. van, McDowell, R. E. and Ford, G. L., 1967. Effect of high temperature and dietary fat on performance of lactating cows. J. Dairy Sci., 50: 1909-1916.

Payne, W. J. A., 1966. Nutrition of ruminants in the tropics. Nutr. Abstr. \& Rev., 36: 653-670. 